\title{
DEVELOPMENT OF INTRA- AND INTERXYLARY SECONDARY PHLOEM IN COCCINIA INDICA (CUCURBITACEAE)
}

\author{
Vidya S. Patil ${ }^{1}$, Carmen R. Marcati ${ }^{2}$ and Kishore S. Rajput ${ }^{1, *}$
}

\begin{abstract}
SUMMARY
Stem anatomy and the development of intraxylary phloem were investigated in six to eight years old Coccinia indica L. (Cucurbitaceae). Secondary growth in the stems was achieved by the normal cambial activity. In the innermost part of the thicker stems, xylem parenchyma and pith cells dedifferentiated into meristematic cells at several points. In some of the wider rays, ray cells dedifferentiate and produce secondary xylem and phloem with different orientations and sometimes a complete bicollateral vascular bundle. The inner cambial segments of the bicollateral vascular bundle (of primary growth) maintained radial arrangement even in the mature stems but in most places the cambia were either inactive or showed very few cell divisions. Concomitant with the obliteration and collapse of inner phloem (of bicollateral vascular bundles), parenchyma cells encircling the phloem became meristematic forming a circular sheath of internal cambia. These internal cambia produce only intraxylary secondary phloem centripetally and do not produce any secondary xylem. In the stem, secondary xylem consisted mainly of axial parenchyma, small strands of thick-walled xylem derivatives, i.e. vessel elements and fibres embedded in parenchymatous ground mass, wide and tall rays along with exceptionally wide vessels characteristic of lianas. In thick stems, the axial parenchyma de-differentiated into meristem, which later re-differentiated into interxylary phloem. Fibre dimorphism and pseudo-vestured pits in the vessels are also reported.
\end{abstract}

Key words: Coccinia indica, interxylary meristem, bicollateral vascular bundles, ray cambium.

\section{INTRODUCTION}

Climbing plants differ from trees and shrubs in a number of characteristics; most notable in the mechanical properties of the stem (Isnard et al. 2003; Lopes et al. 2008). The shift from self supporting to the climbing habit co-occurs with the development of structural patterns, which differ from the more usual anatomical types, and are sometimes referred as anomalous (Cutter 1969) or cambial variant (Carlquist 1988; Sajo \&

1) Department of Botany, Faculty of Science, The M.S. University of Baroda-390002, India.

2) Departamento de Recursos Naturais, Faculdade de Ciências Agronômicas, Universidade Estadual Paulista, UNESP, Campus de Botucatu, SP, Brazil.

*) Corresponding author [E-mail: ks.rajput15@yahoo.com].

Associate Editor: Frederic Lens 
Castro 2006), although these variants may also occur in non-climbing shrubs and trees. Different types of cambial variants occur in lianas that are considered to increase stem flexibility, to protect the conducting elements of xylem and phloem, and to increase storage parenchyma. They may also limit physical disruption of vascular tissues during twisting and bending, and promote wound healing after girdling (Dobbins \& Fisher 1986; Fisher \& Ewers 1992; Lopes et al. 2008); all aspects that are functionally relevant in the lianescent stems.

The Cucurbitaceae contain 97 genera and about 940-980 species (Schaefer \& Renner 2011), in which most of the genera are non-woody and have thus been neglected from a wood anatomical point of view, but there are a few moderately woody genera as well, some of which have been studied anatomically by Carlquist (1992). The stem anatomy of Dendrosicyos socotrana, the only arborescent member of the family, was examined by Olson (2003) who tried to establish correlations to test hypotheses regarding features adaptive to scandent and erect life forms. In this species, stems were mainly composed of very wide rays, parenchymatous conjunctive tissues like lianas, but wide vessels with thick walls were lacking (Olson 2003). According to him, other features such as very wide rays and presence of abundant axial parenchyma in both trees and lianas appear to serve different roles in both life forms (Dobbins \& Fisher 1986; Fisher \& Ewers 1992; Carlquist 2001). The small strands of xylem in Dendrosicyos socotrana were associated with segments of subsequent vascular cambia. This constitutes the first report of successive cambia in the Cucurbitales (Olson 2003). Later, successive cambia were also reported in Bryonia and Ecballium (Schweingruber et al. 2010).

Coccinia is a moderately woody climber but it shares most of the anatomical features reported by Olson (2003) for Dendrosicyos, but it lacks successive cambia. In Coccinia, stem thickness is achieved by several meristematic bands in rays and other parts of the secondary xylem. The radial arrangement of these cells in the meristematic bands gives them a cambium-like appearance.

In India, most of the members of the family are annual herbs, which start growing with the germination of seeds in June with the arrival of rains and complete their life cycle after the dispersal of fruits in January-February. Therefore, in most of the genera secondary growth is limited and stem thickness does not exceed $5 \mathrm{~cm}$. In Gujarat state (India), about 15 genera and 31 species of the Cucurbitaceae are reported (Shah 1978). Among them, Coccinia indica is the only species that is perennial and more woody. Therefore it has been selected in the present investigation to study the pattern of secondary growth. In the dry scrub forest of Gujarat state, Coccinia is one of the main climbing species found growing on Acacia spp.

The presence of two different types of phloem (fascicular and extrafascicular) in the Cucurbitaceae has been recognized for a very long time (Fischer 1883; Crafts 1932). The ease with which phloem sap can be collected and the presence of a unique type of vascular bundles in some cucurbits, have made them excellent candidates for studies of phloem transport and determining the composition of the sap in the conducting sieve elements (Turgeon \& Oparka 2010; Zhang et al. 2010). The fascicular phloem is restricted to either side of the main xylem in the main vascular bundles, whereas extrafascicular phloem forms an anastomosing network that interconnects the vascular 
bundles laterally in the stem and petiole (Turgeon \& Oparka 2010; Zhang et al. 2010). Functionally, fascicular phloem is associated with the transport of the products of photosynthesis and other nutrients over long distances from the leaves to sink tissue. In contrast, Golecki et al. (1999) and Zhang et al. (2010) reported that extrafascicular phloem is associated with the transport of macromolecules, proteins, abundant amino acids and a wide range of unidentified secondary metabolites while it contains very low level of sugars.

In most of the dicots with normal phloem, the seasonal cycle of phloem development has been well studied (Davis \& Evert 1968; Kozlowski 1971; Ghouse \& Hashmi 1983; Vishwakarma 1991; Rajput \& Rao 1998). In general, every year, older and nonfunctional phloem is replaced with new phloem by the seasonal activity of the vascular cambium. Although the anatomy of the Cucurbitaceae is well documented in the majority of reference books, no information is available on the renewal of inner phloem of bicollateral vascular bundles of mature plants, i.e., plants over 6-8 years old. Moreover, the stems of Coccinia are soft due to the abundance of parenchyma cells. What happens to these cells? Do they undergo lignification or are these parenchyma cells subject to collapse and replacement by other cells or cell types?

The main aims of the present investigation were: i) to study the structural alterations occurring in the parenchymatous secondary xylem after 6-8 years, ii) to study whether earlier formed phloem is replaced by new located on the inner side of the bicollateral vascular bundles in 6-8-year-old stems, iii) to study the significance of parenchyma abundance in the stem of Coccinia indica, and iv) to put our results in a comparative context of the anatomical range in the Cucurbitaceae.

\section{MATERIALS AND METHODS}

Eight to ten segments measuring about $10-50 \mathrm{~mm}$ thick and $40-60 \mathrm{~mm}$ in length were collected from the main stems of ten plants of Coccinia indica L. (Cucurbitaceae) growing in the University campus and Arboretum of the Botany Department of the M.S. University of Baroda, India. The plants collected were approximately 6-8 years old. These samples were fixed immediately in FAA (formalin, acetic acid, $70 \%$ ethyl alcohol; $10: 5: 85, \mathrm{v} / \mathrm{v}$ ) and after $12 \mathrm{hrs}$ of fixation cut into smaller pieces and transferred to $70 \%$ alcohol. Suitably trimmed $\left(5 \mathrm{~mm}^{2}\right)$ samples were dehydrated with a tertiary butyl series and processed for paraffin embedding. Thick, unembedded samples were also sectioned on a sliding microtome. Transverse, radial and tangential longitudinal sections of 12-15 $\mu \mathrm{m}$ thickness were obtained with rotary and sliding microtome and stained with safranin and fast green (Johansen 1940).

To obtain the length and width of vessel elements and fibres, small pieces of xylem adjacent to the cambium were macerated with Jeffrey's solution (Berlyn \& Miksche 1976) at 55 to $60^{\circ} \mathrm{C}$ for $24-36 \mathrm{hrs}$, and stained with safranin to study general morphology and dimensional details. For length versus age analysis of vessel elements and fibres, small pieces of xylem were sampled at $2 \mathrm{~mm}$ intervals from pith to cambium and macerated. Length and diameter of the sieve tube elements were measured directly from the tangential longitudinal sections. One hundred measurements were chosen 
randomly to obtain mean and standard deviation for each cell type. The numerical values given in the descriptions are expressed as minimum-maximum with standard deviations in brackets. The term ray cambium is adapted from Carlquist and Hanson (1991) for the ray cells that dedifferentiate into meristematic cells.

\section{RESULTS}

\section{Structure of the secondary xylem}

In Coccinia indica secondary growth in the main stem was achieved by the normal activity of the vascular cambium that formed secondary xylem centripetally and secondary phloem centrifugally. In the 6-8-year-old plants, secondary xylem was diffuse porous with indistinct growth rings with large and heterocellular rays (Fig. 1A, B). The stem was mainly composed of parenchymatous ground tissue, in which thick-walled lignified elements of xylem were embedded as bands. These radial xylem bands were composed of vessels, fibres, narrow sheaths of vasicentric axial parenchyma and some apotracheal parenchyma cells. In transverse view xylem bands were frequently separated by large rays. These wide rays often developed as a polycentric rays, i.e. ray cells dedifferentiate into meristematic centres at several places. These meristematic centres developed into bicollateral vascular bundles (Fig. 1C) with one or two vessels only. Very wide multiseriate rays were 985 to $1478( \pm 23.9) \mu \mathrm{m}$ in height and 18-55 cells wide. In tangential view they were heterocellular and most of the ray cells were procumbent, though square and upright cells were especially found on the ray periphery. Ray cells were 22.8 to $29.6( \pm 2.0) \mu \mathrm{m}$ in diameter and no uniseriate rays or uniseriate wings were observed on multiseriate rays. In the mature stems, parenchyma cells surrounding the inner phloem of the bicollateral vascular bundles redifferentiated into meristematic cells and formed a ring with cells arranged in radial files appearing like a fully closed cambium (Fig. 1D).

Fibres in Coccinia indica were dimorphic: septate libriform fibres with small slitlike pits $(4.5$ to $5 \mu \mathrm{m})$ at narrow angles with the main axis co-occurred with non-septate fibres with relatively large simple pits (with apertures of 3.3 to $4 \mu \mathrm{m}$ ) and wider lumina, giving them a parenchyma-like appearance. Non-septate fibres were 687 to 1125 $( \pm 21) \mu \mathrm{m}$ long and 23.7 to $29.3( \pm 2.5) \mu \mathrm{m}$ in diameter; septate fibres were 1057 to $1279( \pm 25) \mu \mathrm{m}$ long and 20.8 to $24.6( \pm 1.9) \mu \mathrm{m}$ in diameter. The non-septate fibres formed the bulk of cells in which septate fibres were intermingled. It was possible to distinguish both fibre types in macerated material and tangential or radial longitudinal sections but in transverse view they were very difficult to distinguish (Fig. 2A).

Vessels were mostly solitary but radial or tangential multiples of 3-5 vessels also occur. Usually vessels were oval to oblong and often obstructed by numerous tyloses (Fig. 2B), which sometimes completely blocked the lumen. Such tyloses often contained small starch granules. Vessel elements were 185.3 to $268.9( \pm 7.8) \mu \mathrm{m}$ long and 250.7 to $385.4( \pm 8.9) \mu \mathrm{m}$ wide and possessed simple perforation plates in slightly oblique to transverse end walls. The vessel-parenchyma pits on the lateral walls show pseudo-vestured and opposite to alternate with reduced borders, measuring 6 to $10 \mu \mathrm{m}$ in horizontal diameter and 5 to 7 in vertical diameter (Fig. 2C-E). 


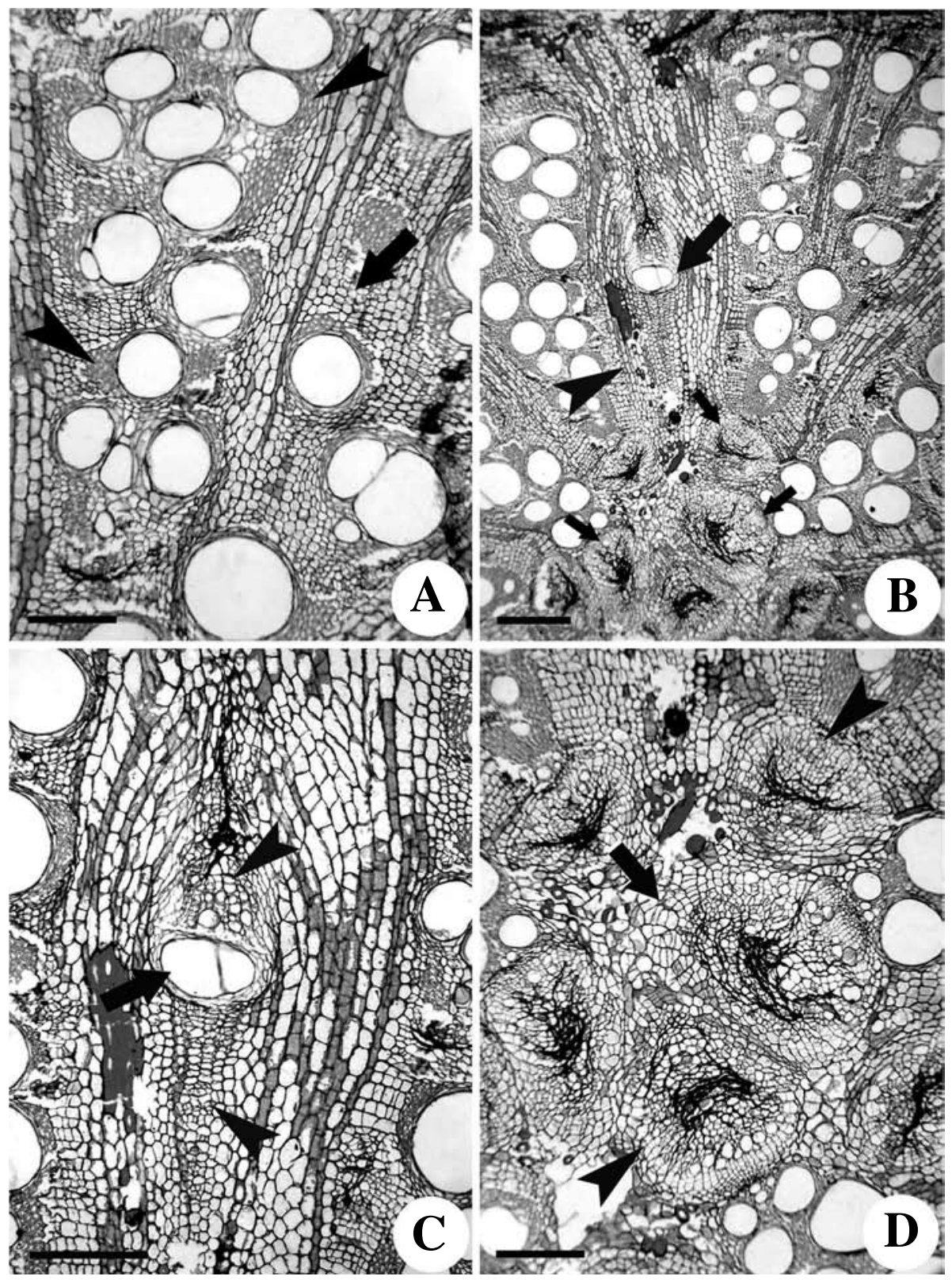

Figure 1. Transverse views of secondary xylem in the mature stem of Coccinia indica. A: Enlarged view of part of Fig. 1B. Note the sheathing of xylem fibres (arrowheads) around the vessels and bands of axial parenchyma (arrows) in the background. - B: Bicollateral vascular bundle in one of the wide rays (arrow); arrowhead indicates ray concentric cambia in the pith region (arrows). - C: Enlarged view of Fig. 1B showing bicollateral vascular bundle with large vessels (arrow) and phloem elements on either side of it (arrowheads). - D: Enlarged view of pith region of Fig. 1B with concentric rings of cambia (arrowhead). - Scale bar $=150 \mu \mathrm{m}$. 

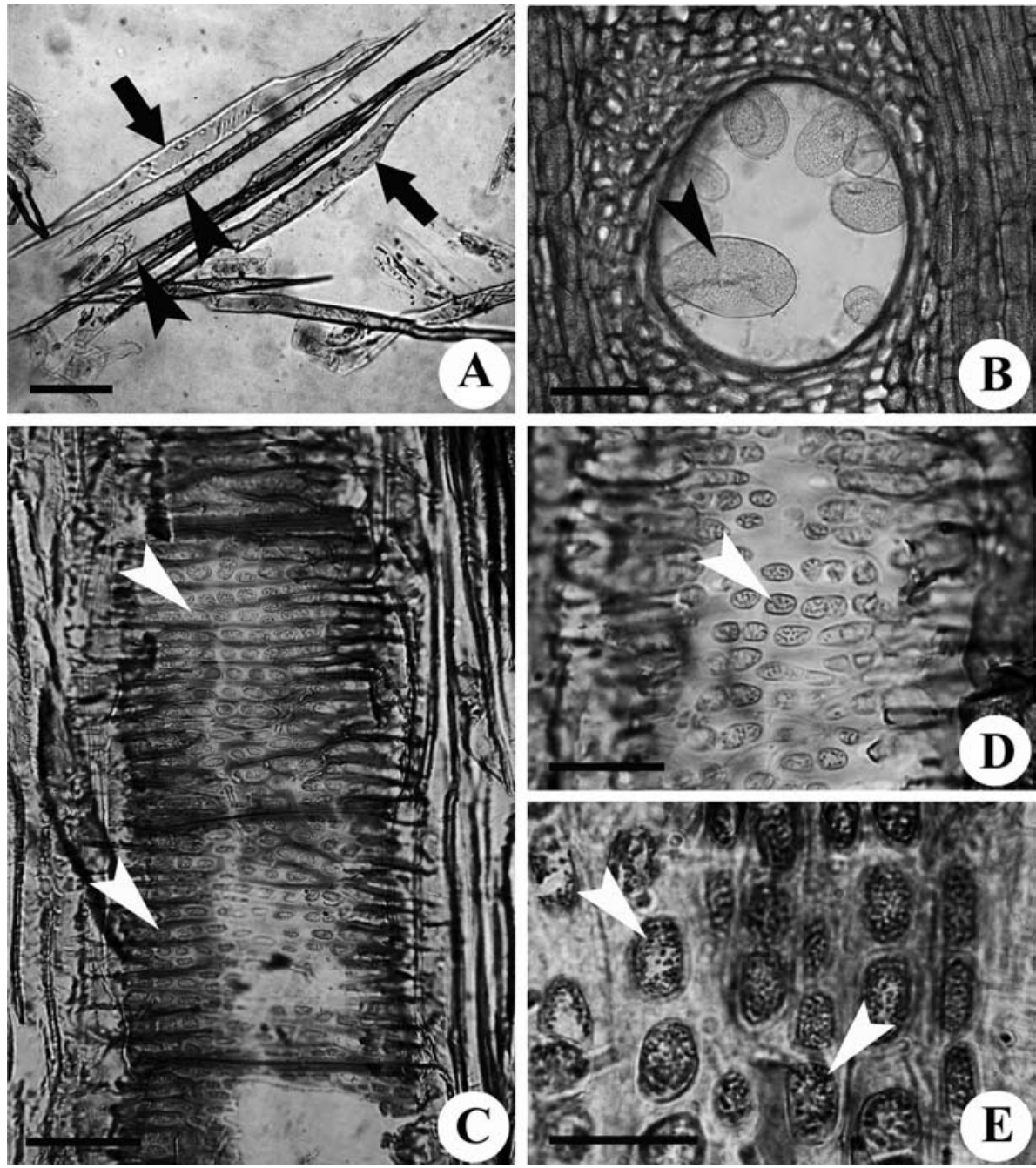

Figure 2. Macerated xylem fibres (A), transverse (B) and tangential longitudinal view (C-E) of vessel elements of Coccinia indica. - A: Fibre dimorphism. Arrowheads indicate relatively narrow septate fibres with thick walls and arrows indicate nonseptate fibres with relatively wide lumina and larger simple pits. - B: Vessel with tyloses (arrowhead). Note the minute starch grains in the tyloses. - C: Vessel elements with simple to bordered pits (arrowheads). - D: Vessel wall showing pseudo-vestured pits (arrowhead). - E: Enlarged view of Fig. 2D showing pseudovestures (arrowheads) in the bordered pits. - Scale bar $=150 \mu \mathrm{m}$ in A-D, $50 \mu \mathrm{m}$ in E.

\section{Development of interxylary and intraxylary secondary phloem}

Interxylary phloem development from the axial and ray parenchyma cells of the secondary xylem can be seen in 6-8-year-old, mature stems (Fig. 3A-E). The development of interxylary phloem from these parenchyma cells may be categorized into three distinct types: i) dedifferentiation of axial parenchyma cells into meristematic 
cells forming concentric rings/circular cambia around intraxylary phloem (Fig. 3A, $\mathrm{B})$, ii) dedifferentiation of axial parenchyma into interxylary meristem that undergo differentiation into sieve tube elements (Fig. 3C-E, 4A) and iii) dedifferentiation of xylem ray cells into meristematic regions and redifferentiation into sieve tube elements (Fig. 4B-E).

In the first type, initially some of the axial parenchyma dedifferentiated into meristematic regions and redifferentiated into isolated strands of interxylary phloem. As the sieve tube elements became non-functional, they collapsed and underwent obliteration. That resulted in radial and tangential expansion of surrounding cells followed by tangential divisions in the surrounding cells (Fig. 3A, B). These strands of interxylary phloem were much more distinct only after the cessation of function by more and more sieve tube elements. Therefore, collapse of the central cells and periclinal divisions in the surrounding cells resulted in the development of several meristematic centres throughout the stem (Fig. 3B). Cells in these meristematic centres differentiated only into the sieve tube elements while differentiation of xylem derivatives was not observed in any of the samples studied.

In the second type, unlignified axial parenchyma cells around the vessel elements dedifferentiated into meristem and redifferentiated into interxylary phloem (Fig. 3C). In this type, the periclinal divisions were arranged in radial files like vascular cambium (Fig. 3D, E). Cell division and differentiation remained unidirectional, thus producing

Figure 3. Transverse views of mature stem of Coccinia indica.-A: Parenchymatous ground tissue showing development of interxylary phloem (upper arrowhead) and concentric rings of cambia (lower arrowhead). Also note the development of interxylary phloem from the parenchyma cells on either side of the vessel (small arrows). - B: Enlarged view of Fig. 3A showing development of the concentric ring of cambium adjacent to one of the vessel elements (arrow). Arrow indicates obliterated nonfunctional phloem. - C: Axial parenchyma cells undergo repeated cell division to form meristematic regions that differentiate into sieve tube elements of interxylary phloem (arrowheads). - D: Enlarged view of Fig. 3C (upper vessel with asterisk) showing interxylary meristematic regions (arrowheads) with interxylary phloem (arrow). - E: Enlarged view of Fig. 3C (lower vessel with asterisk) showing interxylary meristematic region (arrowhead) with interxylary phloem (arrows). - Scale bar $=150 \mu \mathrm{m}$.

Figure 4. Transverse view of mature stem of Coccinia indica showing interxylary phloem and ray cambium. - A: Parenchyma cells between two vessel elements differentiate into interxylary meristem (arrowheads) that produced phloem on opposite sides, thus pushing the cells towards each other and leading to collapse (arrow). - B: Differentiation of ray cambium on either side of the xylem rays (arrowheads). Arrows indicate central ray cells. - C: Development of phloem from ray cambium. Note that newly formed phloem encircles the nonfunctional and crushed phloem (arrowhead). - D: Origin of ray cambium. Note the sequential development of ray cambium from top of the figure towards base (arrowheads) showing swelling of marginal ray cells, radial divisions in the ray cells (arrowhead) and differentiating sieve elements (small arrow). Arrow indicates earlier formed collapsing cells. - E: Differentiation of phloem on all the sides from the ray cambium, thus nonfunctional phloem becomes crushed in the centre (arrowhead).F: Absence of callose from the nonfunctional sieve tube elements that show open sieve pores on the crushed sieve plate (arrowhead). - Scale bar $=150 \mu \mathrm{m}$ in A-E, $50 \mu \mathrm{m}$ in F. 


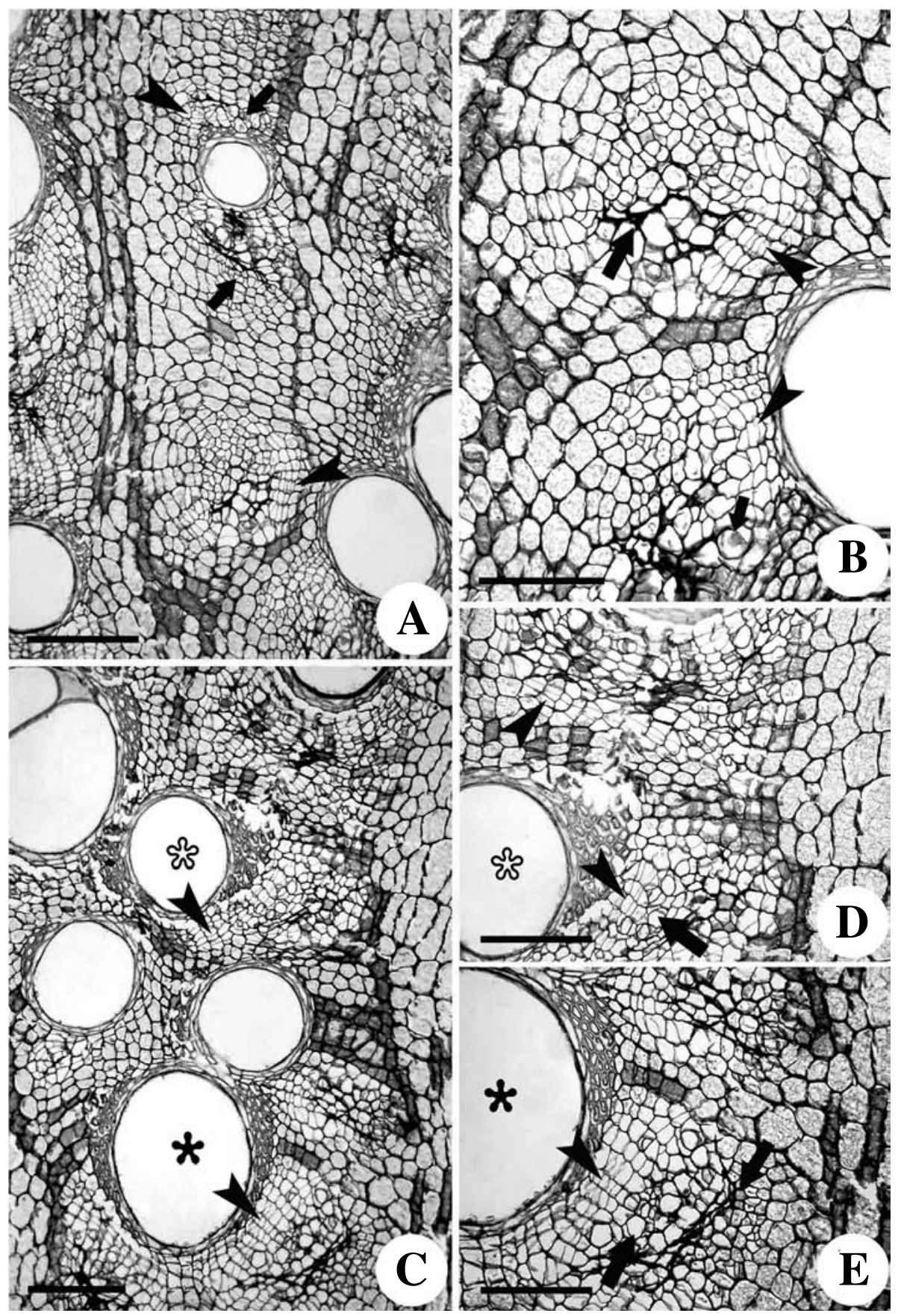

Figure 3 - For legends, see page 481 


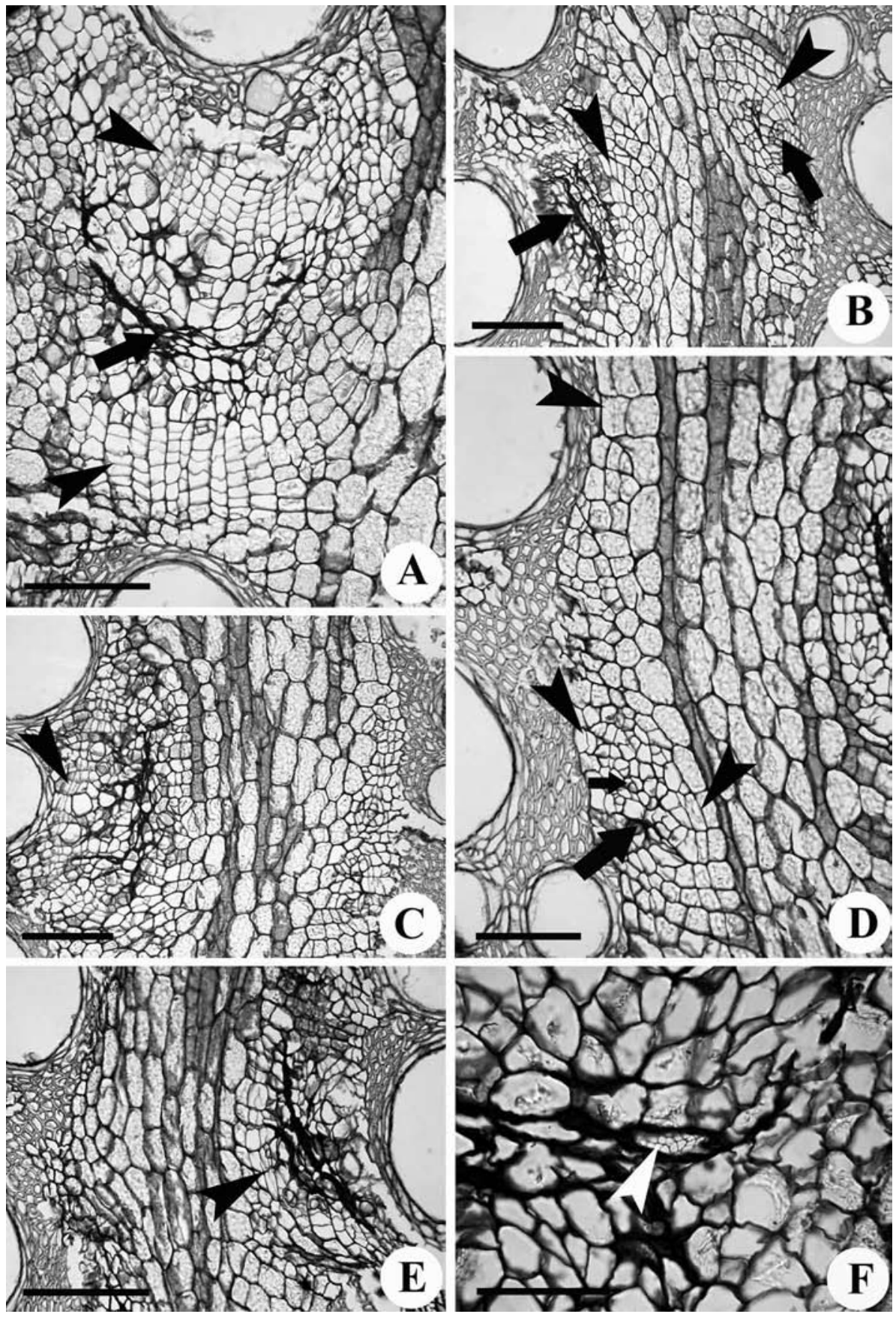

Figure 4 - For legends, see page 481 
only sieve tube elements and no xylem derivatives. Unlike as in the former type, no circular/concentric meristematic rings are formed. The meristematic cells divide irregularly in various orientations. Thus, the meristems may be radially, tangentially or diagonally arranged (Fig. 2C-E, 3A). Sometimes the axial parenchyma between two adjacent vessels dedifferentiated into the meristems (Fig. 4A). Therefore, the meristematic regions located opposite to each other produce more and more phloem derivatives which ultimately met in between these meristematic zones (Fig. 4A).

In the third type, ray cambium was formed by radial or tangential divisions in the unlignified marginal ray parenchyma cells (Fig. 4B). Prior to the development of secondary phloem, marginal ray cells of the xylem situated deep inside the mature stem underwent radial or tangential divisions to form 2-3 layers of meristematic cells arranged in radial files like the vascular cambium (Fig. 4C, D). These cells underwent further divisions and began to differentiate into interxylary phloem. However, divisions in these cells were not synchronized; the origin of phloem from ray cambium differed in different samples or sometimes within the same sample studied. Thus, development of phloem from the ray cambium may be further categorized into two types: i) differentiation of interxylary phloem towards the xylem side (Fig. 4C) consequently resulting into accumulation of phloem between thick-walled xylem derivatives and xylem rays (Fig. 4D) and ii) differentiation of interxylary phloem in the middle of meristematic cells result into differentiation of more and more sieve tube elements (Fig. 4E). Presumably, development of new phloem on either side of the ray cambium always exerted a pressure on earlier formed phloem that ultimately led to the crushing and obliteration of non-functional phloem in the middle of the meristematic band (Fig. 4B, E).

As the phloem becomes non-functional, it loses its turgidity, begins to collapse and is obliterated. The nonfunctional phloem was characterized by accumulation of callose and complete sealing of the sieve pores. Unlike in other dicotyledons, the callose was absent from the sieve plates which were completely obliterated (Fig. 4F).

\section{Paedomorphic features of the xylem}

Secondary xylem is arranged in plates representing an extension of the primary vascular system. Parenchyma cells are abundant, the unlignified, apotracheal parenchyma is arranged in the form of bands or variously shaped patches between the vessels (Fig. 1A). Rays are all multiseriate, in addition to the development of new rays in the fascicular region of the cambium, the interfascicular region of the primary xylem also continued into very high rays of the secondary xylem (Fig. 5A). Ray cells are thinwalled, unlignified and predominantly upright (Fig. 5B), few of them were square while procumbent cells were observed in the middle of the rays in radial longitudinal view. The shape and arrangement of lateral wall pits was altered somewhat by the presence of wide pit apertures which were interconnected by grooves or coalescent pit apertures. Such pits are also referred to as unilaterally compound pits (Fig. 5C, D).

The length-on-age curve of the vessel elements showed an overall negative slope, i.e. vessel element length decreases from the pith towards the periphery (Fig. 6). A similar kind of slopes were observed for the length of both septate (narrow) and non-septate (wider) fibres (Fig. 6). 

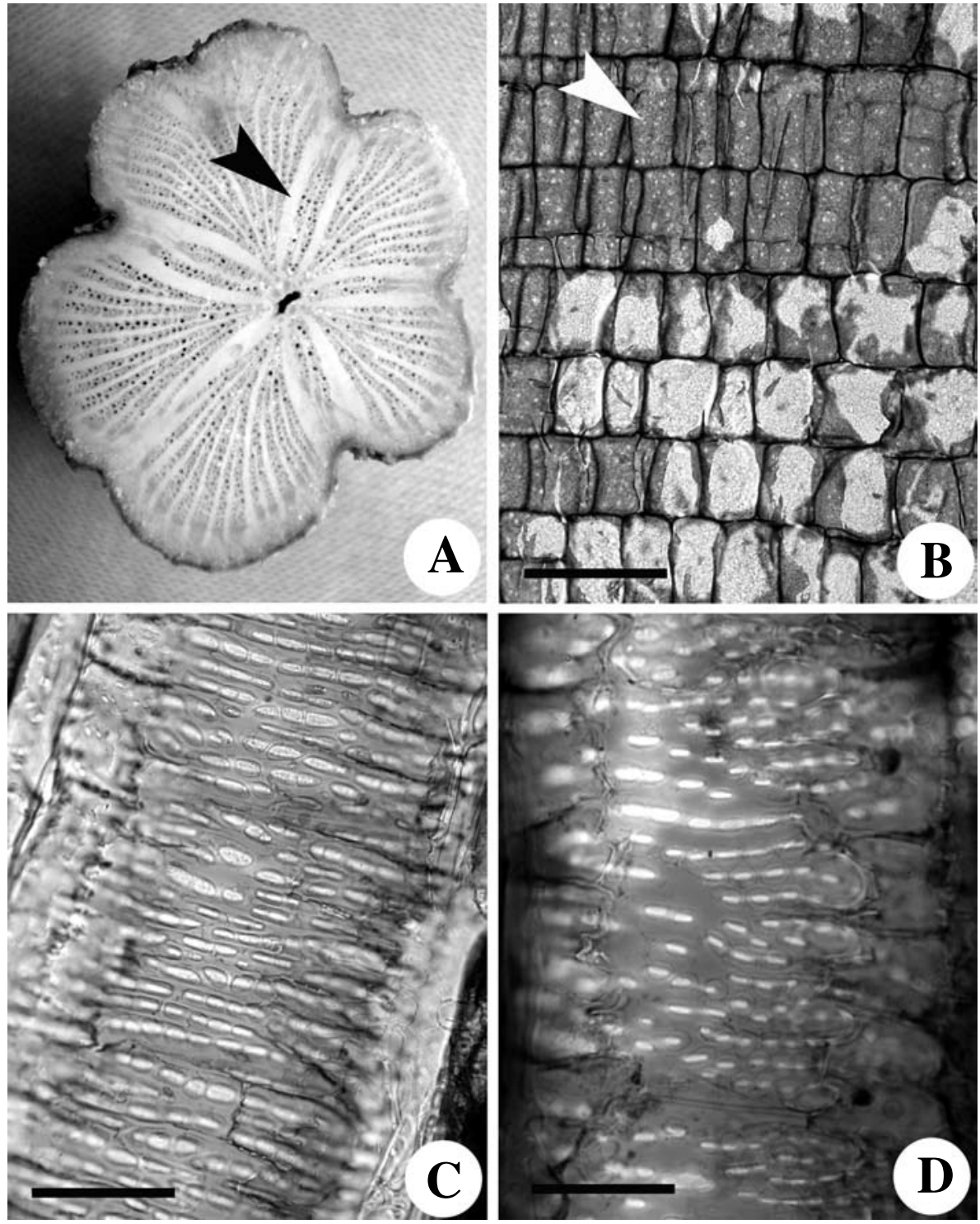

Figure 5. Mature stem (A), radial (B) and tangential (C,D) view of secondary xylem of Coccinia indica. - A: Mature stem (6-7 cm in diameter) showing continuation of rays from pith outward (arrowhead). - B: Portion of a ray showing upright cells (arrowhead). - C: Vessel element wall showing compound pits. $-\mathrm{D}$ : Arrangement of pits on the lateral walls of the vessel elements. Scale bar $=150 \mu \mathrm{m}$. 


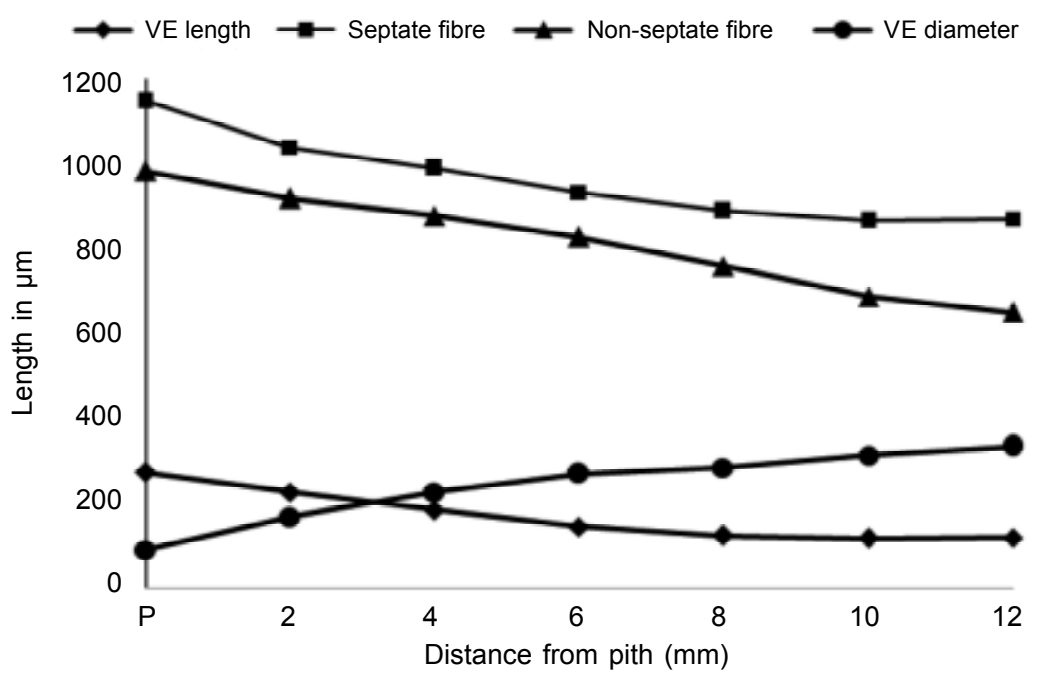

Figure 6. Length-on-age curves for vessel elements, septate and non-septate fibres in Coccinia indica $; \mathrm{VE}=$ vessel element.

\section{DISCUSSION}

Coccinia indica is a perennial climber with bicollateral vascular bundles. In fully grown plants the stem becomes thick, moderately woody, and parenchymatous with very large and wide rays, which is characteristic to almost all the genera of the Cucurbitaceae having tall rays (Carlquist 1992; Olson 2003) and in most of the climbing species (Dobbins \& Fisher 1986; Fisher \& Ewers 1992; Carlquist 2001). In most of the plants a single vascular cambium is responsible for the secondary growth throughout the life of the plants. In the majority of the Cucurbitaceae genera, stems also increase in thickness by a single vascular cambium, but Dendrosicyos socotrana is an exception in the Cucurbitales in having successive cambia (Olson 2003).

Presence of successive cambia in this genus may be associated with its pachycaul/ bottle tree habit. Carlquist (1992) reported similar features in other woody Cucurbitaceae with a 'normal' shrubby/climbing habit. Olson (2003) correlated all the above features with its habit but the above-mentioned characters seem to be characteristic to other woody members of the family as well. However, in Coccinia radial growth is by a single vascular cambium, but several intra-and interxylary strands of meristematic cells arranged in cambium-like radial files also develop in the secondary xylem. These meristematic strands replace the axial and ray parenchyma cells that are undergoing obliteration. The various features of the wood of Coccinia are related directly or indirectly to the scandent habit. Presence of wide vessels in climbing plants is considered to compensate for the small transactional area of secondary xylem (Carlquist 1992). Cucurbitaceae is known for the greater diameter than the length of the vessel elements. Also in the present study average vessel diameter is almost 1.5 times more than its length. 
Abundance of unlignified parenchyma in wood of scandent plants is cited as a feature that provides flexibility to the stem and protects large and vulnerable vessels against torsion and damage (Putz \& Holbrook 1991; Carlquist 1991, 1992, 2001; Olson 2003). Xylem of $C$. indica possesses abundant unlignified axial parenchyma whereas libriform fibres were restricted around the vessels. Libriform fibres were arranged around the vessels in an aliform pattern similar to that of axial parenchyma cells in some woody dicots. Therefore, the strands of secondary xylem are arranged in the background of soft parenchyma and the vessels are sheathed with libriform fibres. This is also known as "cable construction", and has been described in a number of climbing species (Carlquist 2001).

Presence of fibre dimorphism such as in $C$. indica has been reported in several other families (Carlquist 1958, 1961, 1988; Gibson 1977; Mauseth 1999; Melo-de-Pinna 2009) and in the wood of other species of the Cucurbitaceae (Carlquist 1992; Olson 2003. It appears that the non-septate fibres reported by Olson (2003) in Dendrosicyos and in the present study may be the transition between axial parenchyma and fibres, which perform the dual functions of storage of reserve metabolites and mechanical tissue.

It is considered that the lignified thick-walled parenchyma in Coccinia or in "normal' woody plants may prevent damage to wide vessels by enhancing the mechanical strength while thin-walled parenchyma may offer enhanced flexibility to the stem when the torsion occurs. One of the potential advantages claimed for such a construction is the protection of vessels from damage during torsion in stems of lianas (Carlquist 1975). This explanation appears to be valid, because protection from injury is presumably a better option than recovery from injury. Moreover, thin-walled parenchyma cells may be playing an important role in the storage of reserve food material as well as in storage of water. Usually Coccinia grows in scrub forest and sprouting of new leaves occurs during the dryer part of the year before the arrival of rains in the month of June. Thus, abundance of axial parenchyma in the stem of Coccinia may be helpful to store enough water as well as reserve food material to produce a new crop of leaves during the drier part of the year. Recent work on hydraulic conductivity (Lens et al. 2011) of secondary xylem indicates that more cavitation-resistant species are thought to possess shorter vessel elements (Carlquist 1966, 1975; Baas et al. 1983; Lens et al. 2003, 2004, 2009), lower vulnerability indices (Carlquist 1966, 1975), lower mesomorphy indices (Carlquist \& DeBuhr 1977), and more pronounced thickenings on inner vessel walls (Carlquist 1966). In addition, when vessels are embedded in a background of non-conductive fibres and not surrounded by abundant fibres, such as in Acer, xericadapted species are hypothesized to have more and larger vessel multiples than more vulnerable species (Carlquist 1984, 2009; Rosell et al. 2007; Lens et al. 2011). In the present study also xylem shows shorter and wider vessel elements with pronounced thick walls and vessel elements are embedded in a background of non-conductive fibres.

Interxylary phloem islands in the roots of Cucurbita and Lagenaria have been reported by Metcalfe and Chalk (1950). Similarly, bundles of interxylary phloem, arising through the activity of interfasicular cambium, in the unlignified tissue of the primary 
medullary rays of Thadiantha dubia are mentioned by Metcalfe and Chalk (1950). Formation of interxylary phloem by the activity of ray cambium in some members of the Cucurbitaceae has also been reported by Carlquist (1992). In the present study, in addition to the development of ray cambium, formation of interxylary phloem has also found from the axial parenchyma cells. Prior to the development of interxylary phloem, axial parenchyma cells became meristematic and aligned themselves in radial files like the cambium. From this meristematic zone differentiation of interxylary phloem takes place. Various patterns of interxylary phloem development appear to be associated with the collapse of parenchyma cells and sieve tube elements. The empty space formed in response to collapse of parenchyma and sieve tube elements seems to be compensated with newly formed other cells.

Zimmermann (1922) and Carlquist (1992) reported three different kinds of cambial variants in different genera of the Cucurbitaceae. These cambial variants may have similar topographic and physiological significance: providing strands of vascular tissues that do not increase the thickness of a single woody cylinder but instead form vascular strands separated from the main cylinder (Carlquist 1985, 1991, 1992; Putz \& Holbrook 1991). In Coccinia also collapse of the parenchyma cells and formation of interxylary phloem does not appear to contribute to an increase in thickness of the stem.

In the maturing stems, phloem located on the inner side of the bicollateral vascular bundles (of young stems) undergoes obliteration. This non-functional phloem is replaced by addition of new phloem cells by a cambium-like meristem originated from the adjacent parenchyma cells.

Sieve tube elements which become non-functional usually show a massive deposition of callose on sieve plates (Evert 1984; Lawton \& Lawton 1971; Deshpande \& Rajendrababu 1985; Vishwakarma 1991; Rajput \& Rao 1997,1998). Callose along with P-proteins also plays an important role in the sealing of sieve pores by its deposition in non-functional phloem but also blocks the exudation of phloem sap in the wounded portions (Oparka \& Santa Cruz 2000; Turgeon \& Oparka 2010). In our material nonfunctional sieve elements showed very little accumulation of callose on the sieve pores but as the sieve elements began to obliterate, callose gradually disappeared from the sieve plate. Available information indicates that the extrafascicular sieve elements are characterized by scanty or absent callose (Turgeon \& Oparka 2010). Zhang et al . (2010) also reported a very low level of P-proteins in the phloem produced by the fascicular cambium. Thus the sealing function may be performed by other major proteins identified in the fascicular phloem. Absence of callose and P-protein from the phloem is hypothesized to release defense compounds to inhibit pathogens and to protect the sugar-rich phloem from insect and fungal attack (Turgeon \& Oparka 2010; Zhang et al. 2010).

Secondary woodiness refers to woodiness that is derived from herbaceous ancestors whereas paedomorphosis in the secondary xylem refers to a suite of anatomical characteristics, many of which are normally associated only with the primary xylem in typical woody dicotyledons. Paedomorphic features are most often found in less woody plants that have shrubby, suffrutescent, pachycaulous, or lianoid growth forms (Dulin 
\& Kirchoff 2010). In the Cucurbitaceae most of the members are herbaceous climbers and the anatomical features that are used to determine the secondary woodiness and paedomorphosis also suggest that Coccinia grandis shows secondary woodiness.

According to Carlquist's (1962) theory, paedomorphic wood possesses scalariform or pseudoscalariform lateral wall pitting on the vessel elements; vessel elements with simple (most common) or scalariform (less common) perforation plates; wide, thinwalled fibres and the predominance of libriform fibres, or parenchyma cells replacing fibres; either the absence of rays or delayed ray development; and rays, when present, consisting of mostly upright, or square cells; flat or continuously decreasing length-onage curves of vessel elements (Carlquist 1962, 2001, 2009; Lens et al. 2009; Dulin \& Kirchoff 2010). In Coccinia secondary xylem was also characterized by the presence of vessels with simple perforation plates, libriform fibres with thin walls and abundant parenchyma. The ray cells are mostly vertically upright. Presence of two types of fibres representing the transition between fibres and parenchyma may be associated with replacement of fibres with parenchyma cells. The length-on-age variation of vessel elements is also paedomorphic (Fig. 6). Looking to all the paedomorphic features, Coccinia indica shows secondary woodiness. Although paedomorphic anatomical characteristics are indications of juvenilistic wood, by themselves they should not be used to conclude whether the ancestry of a plant is herbaceous or woody (Lens et al. 2009; Dulin \& Kirchoff 2010). That requires robust information of the phylogeny of the clade to which Coccinia indica belongs.

\section{ACKNOWLEDGEMENTS}

The authors (KSR and VSP) are thankful to the University Grants Commission (UGC), Government of India for financial support. Thanks are also due to both the anonymous reviewers and Dr. Frederic Lens for their valuable suggestions on the manuscript.

\section{REFERENCES}

Baas, P., E. Werker \& A. Fahn. 1983. Some ecological trends in vessel characters. IAWA Bull. n.s. 4: 141-159.

Berlyn, G.P. \& J.P. Miksche. 1976. Botanical microtechnique and cytochemistry. The Iowa State University Press, Ames. 326 pp.

Carlquist, S. 1958. Wood anatomy of the Heliantheae (Compositae). Trop. Woods 108: 1-30.

Carlquist, S. 1961. Comparative plant anatomy. Holt, Rinehart \& Winston, New York.

Carlquist, S. 1962. A theory of paedomorphosis in dicotyledonous woods. Phytomorphology 12: $30-45$.

Carlquist, S. 1966. Wood anatomy of Compositae: a summary, with comments on factors controlling wood formation. Aliso 6: 25-44.

Carlquist, S. 1975. Ecological strategies of xylem evolution. University of California Press, Berkeley, CA.

Carlquist, S. 1984. Vessel grouping in dicotyledon wood: significance and relationship to imperforate tracheary elements. Aliso 10: 505-525.

Carlquist, S. 1985. Observations on the functional wood histology of vines and lianas; vessel dimorphism, tracheids, vasicentric tracheids, narrow vessels and parenchyma. Aliso 11: $138-157$. 
Carlquist, S. 1988. Comparative wood anatomy: systematic, ecological, and evolutionary aspects of dicotyledonous woods. Springer, Berlin, Heidelberg.

Carlquist, S. 1991. Anatomy of vines and lianas stems: A review and synthesis. In: F.E. Putz \& H.A. Mooney (eds.), Biology of vines: 53-71. Cambridge University Press, Cambridge.

Carlquist, S. 1992. Wood anatomy of selected Cucurbitaceae and its relation to habit and systematics. Nord. J. Bot. 12: 347-355.

Carlquist, S. 2001. Comparative wood anatomy: systematic, ecological, and evolutionary aspects of dicotyledonous wood. Ed. 2. Springer, Berlin, Heidelberg.

Carlquist, S. 2009. Non-random vessel distribution in woods: patterns, modes, diversity, correlations. Aliso 27: 39-58.

Carlquist, S. \& L. DeBuhr. 1977. Wood anatomy of Penaeaceae (Myrtales): comparative, phylogenetic and ecological implications. Bot. J. Linn. Soc. 75: 211-227.

Carlquist, S. \& M.A. Hanson. 1991. Wood and stem anatomy of Convolvulaceae: A survey. Aliso 13: 51-94.

Crafts, A.S. 1932. Phloem anatomy, exudation and transport of organic nutrients in cucurbits. Plant Physiol. 7: 183-225.

Cutter, E.G. 1969. Plant anatomy: Experiment and interpretation. Part II. Organs. Addison-Wesley Pub. Co., London. 343 pp.

Davis, J.D. \& R.F. Evert. 1968. Seasonal development of secondary phloem in Populus tremuloides. Bot. Gaz. 129: 1-8.

Deshpande, B.P. \& T. Rajendrababu. 1985. Seasonal changes in structure of the secondary phloem of Grewia tileaefolia, a deciduous tree from India. Ann. Bot. 56: 61-71.

Dobbins, D.R. \& J.B. Fisher. 1986. Wound responses in girdled stems of lianas. Bot. Gaz. 147: $278-289$.

Dulin, M.W. \& B.K. Kirchoff. 2010. Paedomorphosis, secondary woodiness, and insular woodiness in plants. Bot. Rev. 76: 405-490.

Evert, R.F. 1984. Comparative structure of phloem. In: R.A. White (ed.), Contemporary problems in plant anatomy. Acad. Press, London.

Fischer, A. 1883. Das Siebröhrensystem von Cucurbita. Botanica Acta 1: 276-279.

Fisher, J.B.\& F.W. Ewers. 1992. Xylem pathways in liana stems with variant secondary growth. Bot. J. Linn. Soc. 108: 181-202.

Ghouse, A.K.M. \& S. Hashmi. 1983. Periodicity of cambium and the formation of xylem and phloem in Mimusops elengi L., an evergreen member of tropical India. Flora 173: 479-487.

Gibson, A.C. 1977. Vegetative anatomy of Maihuenia (Cactaceae), with some theoretical discussions of ontogenetic changes in xylem cell types. Bull. Torrey Bot. Club 104: 35-48.

Golecki, B., A. Schulz \& G.A. Thompson. 1999. Translocation of structural P-proteins in the phloem. The Plant Cell 11: 127-140.

Isnard, T.P., N. Rowe \& T. Speck. 2003. Growth habit and mechanical architecture of the sand dune adapted climber Clematis flammula var. maritima L. Ann. Bot. 91: 407-417.

Johansen, D.A. 1940. Plant microtechnique. McGraw Hill, New York.

Kozlowski, T.T. 1971. Growth and development of trees. Vol. II. Academic Press, New York. $514 \mathrm{pp}$.

Lawton, J.R. \& J.R.S. Lawton. 1971. Seasonal variation in the secondary phloem of some forest trees from Nigeria. New Phytol. 70: 186-196.

Lens, F., P. Gasson, E. Smets \& S. Jansen. 2003. Comparative wood anatomy of epacrids (Styphelioideae, Ericaceae s.1.). Ann. Bot. 91: 835-856.

Lens, F., I. Groeninckx, E. Smets \& S. Dessein. 2009. Woodiness within the SpermacoceaeKnoxieae alliance (Rubiaceae): retention of the basal woody condition in Rubiaceae or recent innovation? Ann. Bot. 103: 1049-1064. 
Lens, F., J.L. Luteyn, E. Smets \& S. Jansen. 2004. Ecological trends in the wood anatomy of Vaccinioideae (Ericaceae s.1.). Flora 199: 309-319.

Lens, F., J.S. Sperry, M.A. Christman, B. Choat, D. Rabaey \& S. Jansen. 2011. Testing hypotheses that link wood anatomy to cavitation resistance and hydraulic conductivity in the genus Acer. New Phytol. 190: 709-723.

Lopes, W.A.L., L.A. Souza, I.M. Moscheta, A.L.M. Albiero \& K.S.M. Mourao. 2008. A comparative anatomical study of the stems of climbing plants from the forest remnants of Maringa, Brazil. Gayana Bot. 65: 28-38.

Mauseth, J.D. 1999. Anatomical adaptations to xeric conditions in Maihuenia (Cactaceae), a relictual, leaf-bearing cactus. J. Plant Res. 112: 307-315.

Melo-de-Pinna, G.F. 2009. Non-lignified parenchyma in Cactaceae and Portulacaceae. Bot. J. Linn. Soc. 159: 322-329.

Metcalfe, C.R. \& L. Chalk. 1950. Anatomy of the dicotyledons. Clarendon Press, Oxford.

Olson, M.E. 2003. Stem and leaf anatomy of the arborescent Cucurbitaceae Dendrosicyos socotrana with comments on the evolution of pachycauls from lianas. Plant Syst. \& Evol. 239: 199-214.

Oparka, K.J. \& S. Santa Cruz. 2000. The great escape: Phloem transport and unloading of macromolecules. Ann. Rev. Plant Physiol. 51: 323-347.

Putz, F.E. \& N.M. Holbrook. 1991. Biomechanical studies of vines. In F.E. Putz \& H.A. Mooney (eds.), The biology of vines: 73-97. Cambridge University Press, Cambridge.

Rajput, K.S. \& K.S. Rao. 1997. Occurrence of ray sieve elements in phloem rays. IAWA J. 18: 197-201.

Rajput, K.S.\& K.S. Rao. 1998. Seasonal development of secondary phloem in Tectona grandis L.f. growing in moist deciduous and dry deciduous forests of Gujarat State. Phyton 38: 251-258.

Rosell, J.A., M.E. Olson, R. Aguirre-Hernandez \& S. Carlquist. 2007. Logistic regression in comparative wood anatomy: tracheid types, wood anatomical terminology, and new inferences from the Carlquist and Hoekman southern Californian data set. Bot. J. Linn. Soc. 154: 331-351.

Sajo, M.G. \& N.M. Castro. 2006. Caule. In: Anatomia Vegetal (eds. B. Appezzato-da-Glória \& S.M. Carmello-Guerreiro): 283-302. Editora UFV, Vicosa.

Schaefer, H. \& S.S. Renner. 2011 . Cucurbitaceae. In: K. Kubitzki (ed.), The families and genera of vascular plants, Vol. X, Flowering plants. Eudicots: Sapindales, Cucurbitales and Myrtaceae: 112-174. Springer, Hamburg.

Schweingruber, F.H.,A. Borner \& E.-D. Schulze. 2010. Stem anatomy of herbs, shrubs and trees; an ecological approach. Springer, Heidelberg.

Shah, G.L. 1978. Flora of Gujarat State. Sardar Patel University, Vallabh Vidyanagar, India.

Turgeon, R. \& K. Oparka. 2010. The secret phloem of pumpkins. Proc. Natl. Acad. Sci. (USA) 107: 13201-13202.

Vishwakanna, A. 1991. Seasonal changes in the structure of the secondary phloem of Odina oodier Roxb., a deciduous tree. J. Indian Bot. Soc. 70: 175-189.

Zhang, B., V. Tolstikov, C. Turnbull, L.M. Hicks \& O. Fiehn. 2010. Divergent metabolome and proteome suggest functional independence of dual phloem transport systems in cucurbits. Proc. Natl. Acad. Sci. (USA) 107: 13532-13537.

Zimmermann, A. 1922. Die Cucurbitaceen. Beitrage zur Anatomie, Physiologie, Morphologie, Biologie, Pathologie und Systematik. Gustav Fisher, Jena. 